\title{
Soil Stability and Groundwater Chemistry in Urban Areas Covered by Loess (Investigation Site - Galati City, Romania)
}

\author{
Mihai Barac ${ }^{1}$, János Kalmár ${ }^{2}$, László Kuti² \& József Vatai ${ }^{2}$ \\ ${ }^{1}$ The National Research and Development Institute for Land Reclamation - "ISPIF", Bucharest, Romania \\ ${ }^{2}$ Hungarian Geological and Geophysical Institute, Budapest, Hungary \\ Correspondance: János Kalmár, Hungarian Geological and Geophysical Institute, Budapest, Stefánia út 14, \\ Hungary. E-mail: johannkalmar@gmail.com
}

$\begin{aligned} & \text { Received: February 22, } 2013 \quad \text { Accepted: May 23, } 2013 \quad \text { Online Published: July 19, } 2013 \\ & \text { doi:10.5539/esr.v2n2p214 }\end{aligned} \quad$ URL: http://dx.doi.org/10.5539/esr.v2n2p214

\begin{abstract}
Galati city is located on the left side of the Danube river, close to the Danube Delta (Romania). Local deformation of the soil and of the constructions signalized some instability phenomenon on the geological background. For this reason, in the southern part of the city, in the newly built quarters of block of flats, a large network of shallow boreholes was performed. In this paper, a small $\left(0,75 \mathrm{~km}^{2}\right)$ model area was studied. In the boreholes and on the steep riverside of the Danube, Upper Pliocene, Middle and Upper Pleistocene deposits were identified and analyzed: the Poiana Formation, the Barbosi Formation and the Würmian loess. The variation of the depth and the chemistry of the groundwater were also studied. In our study, we try to distinguish the variation of the natural (geological) components of the soluble salts to the anthropogenic pollutants as $\mathrm{K}^{+}, \mathrm{NH}_{4}^{+}$ $\mathrm{Cl}^{-}, \mathrm{SO}_{4}^{-2}, \mathrm{NO}_{3}^{-}, \mathrm{NO}_{2}^{-}, \mathrm{PO}_{4}$ and some trace element ions. Note, that some ions as $\mathrm{K}^{+}, \mathrm{Cl}^{-}, \mathrm{SO}_{4}^{-2}$ could have both natural and man made origin. The spatial distribution of the concentration of these components shows a difference between them because of interaction between the groundwater and the mineral components (mainly of the clay minerals) of the deposits: one part of the ions is released, while the others are "braked" in their movement. This way, an anomalous zone was identified in the centre of the model area, which was probably caused by the damaged sewerage network: the "aggressive" components of the slurry reacted with the loess, causing the breakdown of the macroporous structure of them.
\end{abstract}

Keywords: Galati city, Pleistocene, loess, groundwater chemistry, pollution, building instability

\section{Introduction}

Loess is the most common aeolian sediment in Eastern Europe and in Central and Eastern Asia. In Romania and in Hungary, during Würm glacial period, large surfaces were covered by a yellowish, porous siltic deposit with a thickness of approximately $10 \mathrm{~m}$. In the humid periods of Holocene, on the loess covered by forests, and in wet plain regions as well, fertile soil cover was formed. From human point of view, the loess moulds and hillocks were occupied by the first Neolithic settlements. In Romania, the recent Galati city is one of them.

The loess plateau of approximately $80-90 \mathrm{~m}$ high which dominates the Danube floodplain was populated from the beginning of the Neolithic age (Hamangia ceramics; Predescu, 1971). The name of the locality is coming

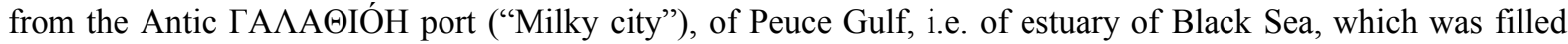
later by the Danube Delta (Cotet, 1971). The actual settlement was founded by Prince Stefan II of Moldavia (1447). During the XVII ${ }^{\text {th }}$-XVIII ${ }^{\text {th }}$ centuries, it became the main Danubian commercial centre (www.galati.ro). An important steel plant was implemented here in the second half of $\mathrm{XX}^{\text {th }}$ century. However, by the construction of the block of flats quarters for increased urban population, having buildings of 4-8 floors (Tiglina quarter), certain stability problems were observed in loess ground. At the end of the '60s, deformation of asphalt cover of the inner roads, some fissures in the foundations and in the walls of several constructions signalized that in this site, the equilibrium between the ground, the building objects and the hydrologic-hydrogeologic system was disturbed. Therefore, appropriate geological and geotechnical research was followed. In this paper, we present the results of field and laboratory studies performed on an experimental area of Galati city. 



Figure 1. Galati city and its environs: geological sketch after Saulea et al., 1968

Legends: 1. Holocene floodplain of Danube and Prut rivers; 2. Upper-middle Pleistocene loess; 3. Middle Pleistocene Barbosi Formation; 4. Upper Pliocene - Early Pleistocene Poiana Formation; 5. North Dobrogean Crystalline and Paleozoic Basement.

\section{Materials and Methods}

\subsection{Aims and Observations}

According to our conception, the sediment, the groundwater and the built assemble form an interlaced, dynamic system. If one of the components is changed, the whole system will be affected (Szurkos \& Zsámbok, 2005). In this case, the deformation of buildings and of road network shows, in fact, the physical and/or mineralogical changes of sediments in correlation with the state of the groundwater. Therefore, the prevention and the reparation of damages could be successfully only if the composition of the subjacent sediment column and the peculiarities of the groundwater are known.

For this reason, in Galati city, a large network of shallow boreholes was performed. The drillings works started between 1973-74 and they were performed by ISPIF Bucuresti. The stratigraphy, the physical and geotechnical properties of the sediments, the depth and the chemistry of the groundwater table were studied. The investigations were continued until 2007, mainly by hydrogeological observations in wells and by topographic measurements, marking the deformation of the surface. From this point of view, the most interesting site seems to be the $0.75 \mathrm{~km}^{2}$ extended quarter, situated between Brailei, Navelor, Alexandru Cernat streets and The Great Union Avenue, as model area (25 shallow boreholes were drilled). Our observations are based on several data obtained both from these boreholes and from others existing close to our model area.

Presenting these problems, we intend to offer an appropriate model for analyzing similar situations in built, urban sites.

\subsection{The Geological Background}

From geological point of view, Galati city is located at the intersection of three great geological units of Romania: the Moldavian Platform (at the westernmost edge of the East European Plate), the Moesian Microplate (Romanian Plain) and the Kimmerian Dobrogea Highland (Botezatu, Bacioiu, \& Andrei, 1961). Here the Paleozoic crystalline basement which outcrops near Buceag and Orliga hills of Northern Dobrogea sinked more than $3000 \mathrm{~m}$ below Cretaceous, Neogene and Pleistocene fluvial and shoreline deposits (Macarovici \& Jeanrenaud, 1958).

Galat city is oriented to NW-SE, on a weakly inclined platform, on the top of which the Galati Steel Plant and the new town called "Tiglina" were built. The southern limit of the city is the Danube, along a steep riverside (the "falaise"), on which now a promenade way is going.

In the surroundings of the studied area, Upper Pliocene, Pleistocene and Holocene deposits occur (Saulea, Ghenea, Bandrabur, \& Ghenea, 1968).

Upper Pliocene. The oldest outcropping level of this area is represented by Poiana Formation: grey sand, with clay and thin sandstone levels (Macarovici, 1929), which outcrops along small rivulets located both on the northern side (Smardan, Tulucesti) and on the western part of the city (Negreia-Schela line). TheVillafranchian age was proved by the rich Mollusca and Mammalia fauna from Tulucesti. Now, the upper part of Poiana sands is considered to be early Pleistocene. 


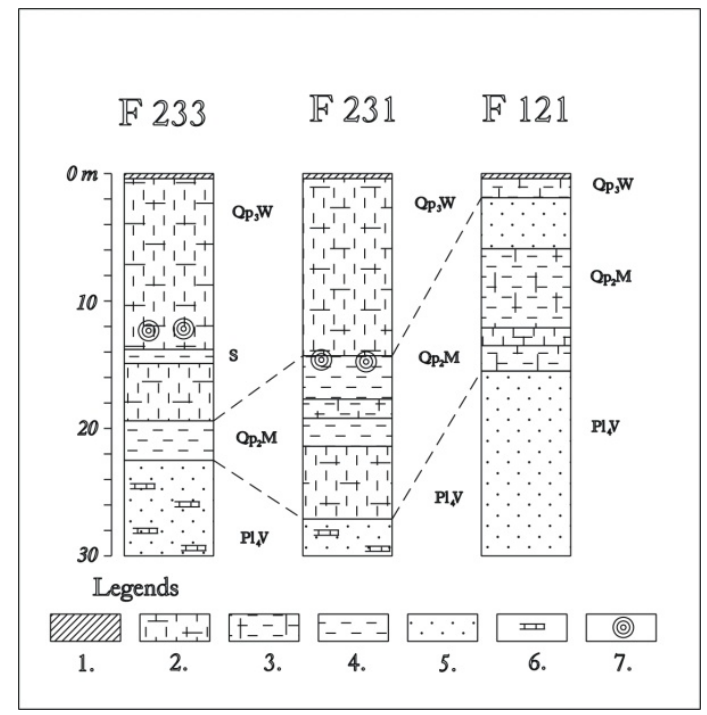

Figure 2. Lithologic-stratigaphic columns of some boreholes, SW of Galati city

1. Soil and up filling; 2. Clayey silt; 3. Silty clay; 4. Clay; 5. Sand; 6. Sandstone lenses; 7. Lime concretions. $\mathrm{Qp}_{3} \mathrm{~W}$ : Upper Pleistocene loess; $\mathrm{Qp}_{2} \mathrm{M}$ : Middle Pleistocene clayey-silty Barbosi Formation; $\mathrm{Pl}_{4} \mathrm{~V}$ : Upper Pliocene-early Pleistocene sandy Poiana Formation.

Pleistocene. In boreholes and in outcrops along the Danube riverside, Middle and Upper Pleistocene were identified, as follows:

- Middle Pleistocene: Barbosi Formation. The brown-reddish and grey clay with clayey sand and sand levels, with brakish Mollusca fauna belongs to the Palaeoeuxinic Stage of the Black Sea (Mindel, below the Matuyama - Gauss Inversion, after Liteanu, Pricajan, \& Baltac, 1961). In outcrops (Braniste-TraianBarbosi line) and in boreholes, the Barbosi Formation has a thickness between 10-25 m.

- The upper part of the Middle Pleistocene and the whole Upper Pleistocene (Würm) are represented by loess and loess-type deposits (Sficlea, 1960). In our boreholes (Figure 2), the thickness of these sediments varies between 20-50 m, containing 3-5 palaeo-soil levels (reddish brown clayey silt and silty clay with lime concretions).

Holocene. The sandy-loamy deposits of the Danube floodplain represent both the Early Holocene (Flandrian transgression, 5000 years BP) and the Late Holocene, the second one having the same age as the deposits of the Danube Delta (Cotet, 1971).

\subsection{Hydrogeology}

In the whole Tiglina quarter and, in our model area as well, the groundwater table was situated at $5-10 \mathrm{~m}$ bellow the surface (1973), decreasing to a depth of $28 \mathrm{~m}$, in time (2007). The hydro-isohypse map shows, that the groundwater flows from the higher points of the loess platform toward the Danube riverside. There, at the base of the mentioned "falaise", before the land regulation, a line of springs emerged. The impermeable level of the groundwater is the Barbosi clayey-silty formation, and the water keeping one is the Würmian loess.

During the past 34 years, the hydro-isohypses changed not only their values, but their configuration has sensibly deformed: the minimal point of them, from the western side of the model area has withdrawn toward its north-eastern limit.

The initial chemical character of the groundwater was hydro-carbonated, calcic and sodo-calcic. Now, in some wells, the chemistry of the groundwater had important changes both in the main and in the secondary components (see Chapter 3).

\subsection{Lithology and the Geotechnical Characteristics}

The sediments which form the studied model area constitute the geotechnical medium, on which the block of flats was built up. The groundwater flows through these sediments. For this reason, we present their lithological characterization and mechanical properties. 
Table 1. The mechanical composition of some sediment samples

\begin{tabular}{|c|c|c|c|c|c|c|c|c|c|c|c|}
\hline $\begin{array}{c}\text { Grain size, } \\
\mathrm{mm}\end{array}$ & $<0.002$ & $0.002-0.005$ & $0.005-0.01$ & $0.01-0.02$ & $0.02-0.063$ & $0.063-0.1$ & $0.1-0.2$ & $0.2-0.3$ & $0.3-0.5$ & $0.5-1.0$ & Total \\
\hline \multicolumn{12}{|c|}{ Barboşi Formation } \\
\hline $\begin{array}{c}\text { F220, } \\
22-23 \mathrm{~m}\end{array}$ & 35.2 & 18.3 & 10.5 & 8.1 & 10.3 & 11.0 & 4.5 & 1.1 & 0.7 & 0.3 & 100 \\
\hline $\begin{array}{c}\text { F231, } \\
16-18 \mathrm{~m}\end{array}$ & 53.5 & 10.3 & 5.5 & 8.5 & 12.3 & 8.3 & 0.5 & 0.5 & 0.2 & 0.4 & 100 \\
\hline $\begin{array}{c}\text { F233, } \\
14-15 \mathrm{~m}\end{array}$ & 58.2 & 12.8 & 8.5 & 4.5 & 5.0 & 4.3 & 6.5 & 0.2 & & & 100 \\
\hline \multicolumn{12}{|c|}{ Loess Formation } \\
\hline $\begin{array}{c}\text { Navelor } \\
\text { street }\end{array}$ & 18.0 & 6.0 & 4.4 & 11.5 & 55.1 & 2.8 & 1.2 & 0.3 & 0.2 & 0.5 & 100 \\
\hline $\begin{array}{l}\text { F } 220, \\
10-11 \mathrm{~m}\end{array}$ & 15.4 & 8.0 & 5.5 & 9.5 & 46.0 & 6.4 & 3.9 & 3.3 & 1.5 & 0.5 & 100 \\
\hline $\begin{array}{c}\mathrm{F} 254, \\
16-17 \mathrm{~m}\end{array}$ & 12.5 & 10.2 & 6.5 & 5.8 & 40.5 & 12.8 & 6.2 & 2.5 & 2.0 & 1.0 & 100 \\
\hline
\end{tabular}

\subsubsection{The Barbosi Formation}

All around Galati area mainly the upper, clayey level of the Barbosi Formation plays a role as an impermeable bed. The grain size distribution of this level shows a large variety of clay: from typical clay to silty-sandy clay (Table 1), with 2-13\% carbonate content and $\mathrm{pH}$ 6.8-8.3. Note that the carbonate content is higher in samples with lime concretion, which appear mainly in the loess/clay boundary zone.

The mineralogical composition of brown-red clay samples from the top of the Barbosi formation (Table 2) shows high clay mineral contents (34\%), in which the expandable montmorillonite is the main mineral. Among the non clay minerals, the quartz dominates, with scarce content of feldspars. The carbonate content is negligible. The hematite (2\%) is responsible for the red colour of this sediment. Note the presence of gypsum, which may be considered as the relict of brackish sea water sediment.

Table 2. Mineralogical composition of some sediment samples

\begin{tabular}{lrr}
\hline Location, $\mathrm{m}$ & F231, $16-18 \mathrm{~m}$ & Str. Navelor \\
\hline Sediment type & Red clay & Clayey loess \\
Montmorillonite & 12 & 3 \\
Illite/montmorillonite mixed layer & 3 & \\
Illite+muscovite & 14 & 8 \\
Kaolinite+chlorite & 5 & 3 \\
Quartz & 50 & 68 \\
K-feldspar & 3 & 4 \\
Plagioclase & 2 & $\mathrm{tr}$ \\
Amphibole & $\mathrm{tr}$ & $\mathrm{tr}$ \\
Calcite & 3 & 10 \\
Dolomite & & 2 \\
Gypsum & 2 & \\
Goethite & $\mathrm{tr}$ & $\mathrm{tr}$ \\
Hematite & 2 & \\
Amorphous & 4 & 2 \\
Total \% & 100 & 100 \\
\hline
\end{tabular}

The grain size distribution and the mineralogical composition, as well, are reflected in the geotechnical characteristics of these sediments. In Table 3 we present the data from 34 measurements. 
Table 3. The geotechnical characteristics of some sediment samples

\begin{tabular}{lrr}
\hline Geotechnical characteristics & Bărboşi Formation & Loess Formation \\
\hline Plasticity index $\mathrm{I}_{\mathrm{p}}$ & $8.5-50.5$ & $10.0-25.5$ \\
Natural humidity w\% & $17.0-32.2$ & $6.0-22.1$ \\
Consistency index $\mathrm{I}_{\mathrm{c}}$ & $0.39->1$ & $0.45->1$ \\
Natural volume weight $\mathrm{g}, \mathrm{kN} / \mathrm{m}^{3}$ & $19.3-20.7$ & $10.0-20.3$ \\
Porosity, $\mathrm{n}(\%)$ & $35.4-48.8$ & $35.0-59.5$ \\
Pore index, e & $0.87-1.0$ & $0.12-0.84$ \\
Saturation degree $\mathrm{S}_{\mathrm{r}}$ & $0.55-0.9$ & $0.71-0.92$ \\
Edometric deformațion module $\mathrm{M}_{2-3}(\mathrm{kPa})$ & $9100-25000$ & $4150-25000$ \\
Specific compaction $\varepsilon(\%)$ & $1.3-2.6$ & $0.6-8.6$ \\
\hline
\end{tabular}

The sediments sampled from the boreholes are heterogeneous, so that the presence of sandy lenses and limy concretions cause the large spreading of these values. Thus, the Barbosi red-brown clayey-silty sediments are characterized by "medium" to "high" plasticity, the consistency between "plastic-soft" to "hard", the compressibility between "scarce" and "high"; the saturation degree varying between "humid" and "wet".

Because these deposits are buried under a few tens of meters of loess, despite of their unfavourable mechanical properties, their influence regarding the soil stability is scarce. On the contrary, from a hydrogeological point of view, the (hidden) relief of these impermeable sediments constitutes the "pathway" of underground water flows, below buildings and roads.

\subsubsection{The Loess and Loess-Type Deposits}

The whole model area is covered by loess and - on the south eastern and eastern sides - by eroded, weakly moved and newly deposited slope sediments, i.e. loess-type deposits. Now, it is difficult to distinguish between the natural slope deposits (deluvial loess) and the man-moved and compacted loess fillings among the blocks.

The grain size distribution (Table 1) of these sediments shows typical aeolian deposit, with high proportion of $0.02-0.063 \mathrm{~mm}$ fraction. The relatively high $(>20 \%)$ clay fraction characterizes the South Moldavian and Dobrogea loess deposits from Romania (Ghenea \& Ghenea, 1959; Saulea et al., 1968).

In several boreholes, with a thickness of $0.5-2.0 \mathrm{~m}$ brown clays were intercepted. They probably represent rests of the buried (fossil) soil levels.

The mineralogy of the loess samples (Table 2) shows the dominance of quartz (more, that $60 \%$ ). The amount of the clay minerals varies around $10 \%$, among which illite is the most dominant. The carbonates represent the essential components of the loess, as concretions, as pore fillings and as the part of clay-carbonate-iron hydroxide fine grained mixture.

The values of the geotechnical characteristics (Table 3) vary on large scale, and this proves the heterogeneity of this sediment: the plasticity varies from "scarce" to "high", the consistency from "plastic-soft" to "hard", the compressibility, from "very low" to "very high", and the saturation index between "wet" and "dry".

This variability is caused by the presence (or absence) of the water in the sediment pores. Thus, the mechanical behaviour of loess below groundwater table, with saturated pore space differs substantially from that of the dry loess, with high porosity, mainly with "macroporous" character: root and worm channels, rodent holes ("crotovinas"), opened drying cracks, etc. In this sieve-like earth, the precipitations penetrate the sediment without any structural damages. On the contrary, in the saturated zone, the breakdown of the macropores will be produced and the loess collapses, which leads to low mechanical resistance and to deformations of the land surface. The presence of some chemical substances in the groundwater accelerates this negative phenomenon.

In the collapsed loess, the groundwater is "obliged" to percolate in the subcapillar pore space, being in close contact with the finest mineral fraction, mainly with clay minerals. Under these circumstances, the water and the dissolved components follow different ways, i.e. a fractionation of ionic components will be produced (Gieseking, 1975). 


\section{Groundwater Chemistry and Ground Stability}

In 1973-74, in the sampled wells, hydro-carbonated, calcic and sodo-calcic water with $\sim 600 \mathrm{mg} / 1 \mathrm{soluble}$ salt content was found. But during the last quarter of the century, not only its position, but its chemistry has changed too.

In 2007, in a few newly bored wells, a notable change in the chemical composition of the water was noticed. Thus, the total salt concentration increased by 2-6 times and in central part of the model area, a large, elliptical maximum of the concentration, with an apex at $3127.87 \mathrm{mg} / \mathrm{l}$ was found (Figure 3). High values of all the analyzed components and of trace element concentrations were evidenced too.

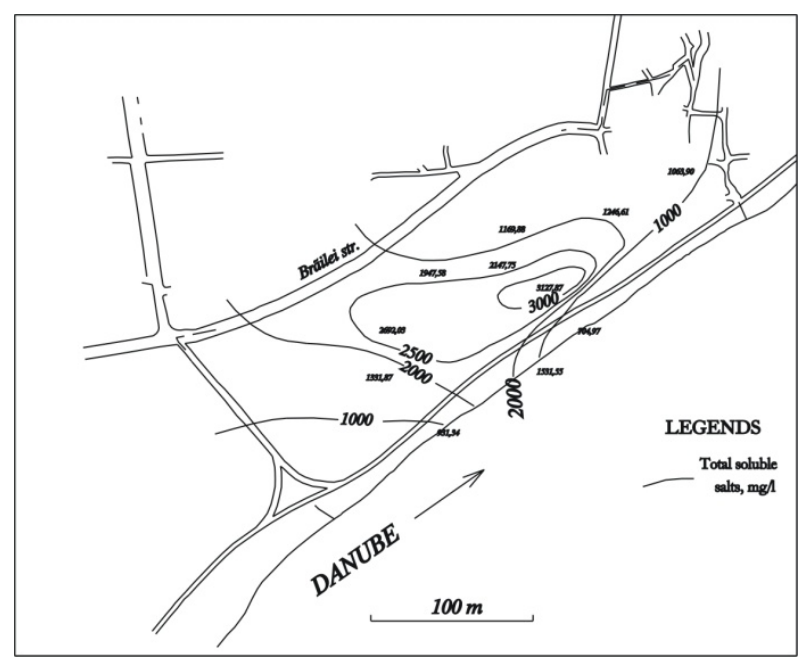

Figure 3. Total dissolved salt concentration in the groundwater of the model area

Changes in the groundwater composition appeared as a result of natural and anthropogenic causes. It is known, that in all European countries, during the last 30-40 years, the amount of precipitations was under the multi annual average and the Moldavian - Dobrogean territory was affected by long drought periods. During this time period, the surface infiltration (which is the main water source for aquifer formations) was diminished (or locally stopped) because of the extended built surfaces (block of flats, sidewalks, and roads). Here, the rainwater is collected by the sewerage network and/or it streams directly into the Danube river.

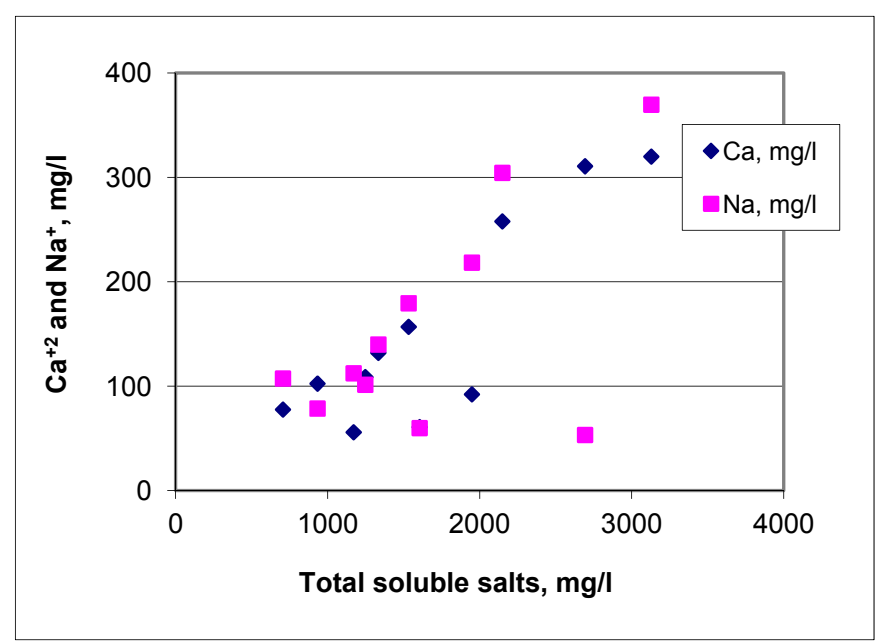

Figure 4. The correlation between the total salt content and respectively, the $\mathrm{Ca}^{2+}$ and $\mathrm{Na}^{+}$concentration in the groundwater samples 
Despite of the increased salt concentration, the basic hydro-carbonated, calcic and sodo-calcic character of the groundwater did not change: i.e. the $\mathrm{Ca}^{+2}$ and $\mathrm{Na}^{+}$concentrations correlate with the increasing soluble salt content (Figure 4). In the same time, we observed the increased concentration of some ions, which may have both natural (geological) and anthropogenic origin: the $\mathrm{K}^{+}, \mathrm{NH}_{4}^{+}$cations and the $\mathrm{Cl}^{-}, \mathrm{SO}_{4}^{-2}, \mathrm{NO}_{3}^{-}, \mathrm{NO}_{2}^{-}$and $\mathrm{PO}_{4}^{-}$ anions and as well, the $\mathrm{Cr}, \mathrm{Cu}, \mathrm{Ni}$ and $\mathrm{Zn}$, as trace elements.

Therefore, can we distinguish the natural, increased background to the pollution? We suggest (i) to show the correlation among the main, natural components and these ones, and (ii) to compare the aspects of the concentration (iso-line) maps (Figure 5).

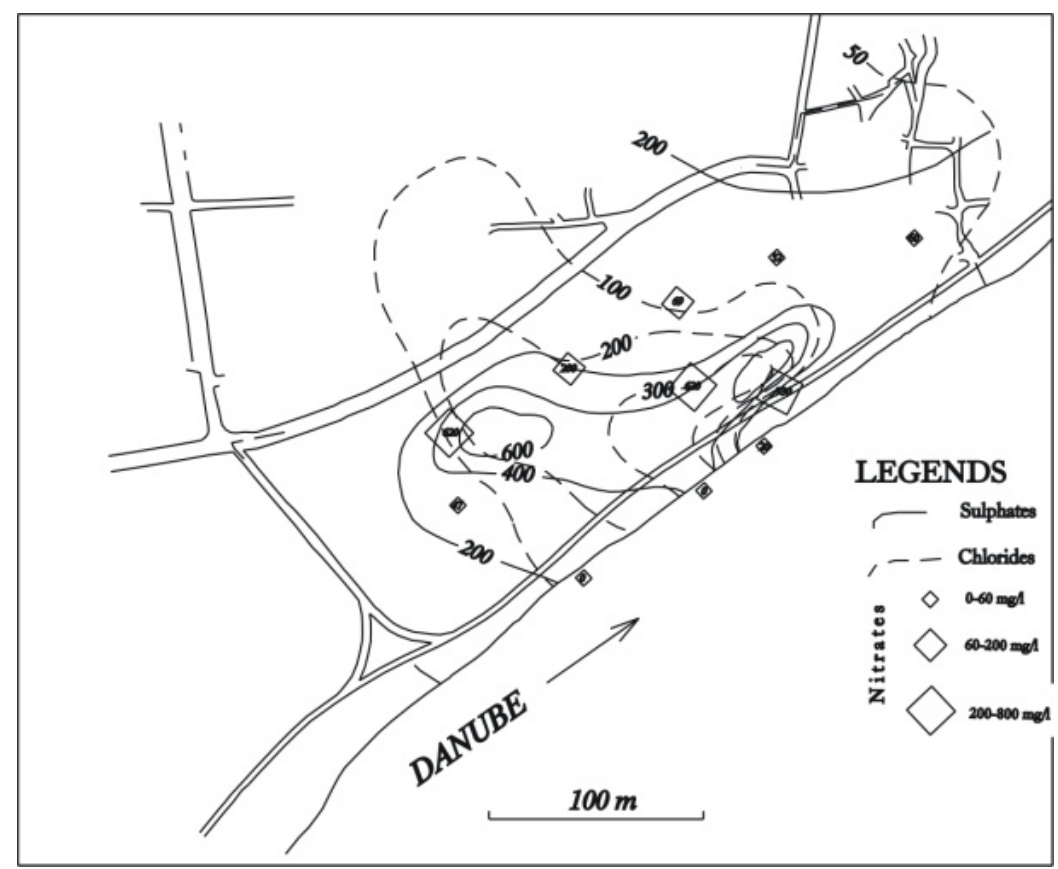

Figure 5. Variation of sulphate, chloride and nitrate ion contents of the groundwater

The aspects of iso-lines for $\mathrm{K}^{+}, \mathrm{SO}_{4}^{-2}$ and $\mathrm{Cl}^{-}$, show a similar contour and their apex is close to the apex of the total soluble salts, but it is far from being identical. Therefore, these components could be considered natural (illite, gypsum in Barbosi clay, salt in the rainfalls from Black Sea), with or without anthropogenic supply: potassium and chlorides from human dejections, sulphates from the leaching of concrete and from acid rainfalls as well $\left(\mathrm{SO}_{2}\right.$ emitted by the steel plant situated close to the site). Except $\mathrm{Cu}$, the trace elements show similar spatial distribution. Probably, the cooper content $(0.06-0.86 \mu \mathrm{g} / \mathrm{l})$, goes together with the natural elements are coming from the former vineyards of this place; the grape plants were treated with cooper sulphate, against fungi diseases.

The ammonium cations, the nitrates, nitrites and phosphates do not correlate with the natural components (Figure 6). The maximum concentration of these components appears in the centre of the model area, close to F795 well (Figure 7).

Here the asphalt cover of Florilor walkway was repeatedly broken, and on the surface of the lawn, small depressions were formed. It is possible, that the sewerage network is damaged and the ground deformation is caused by the interaction between the loess and the chemical components of the slurry. 

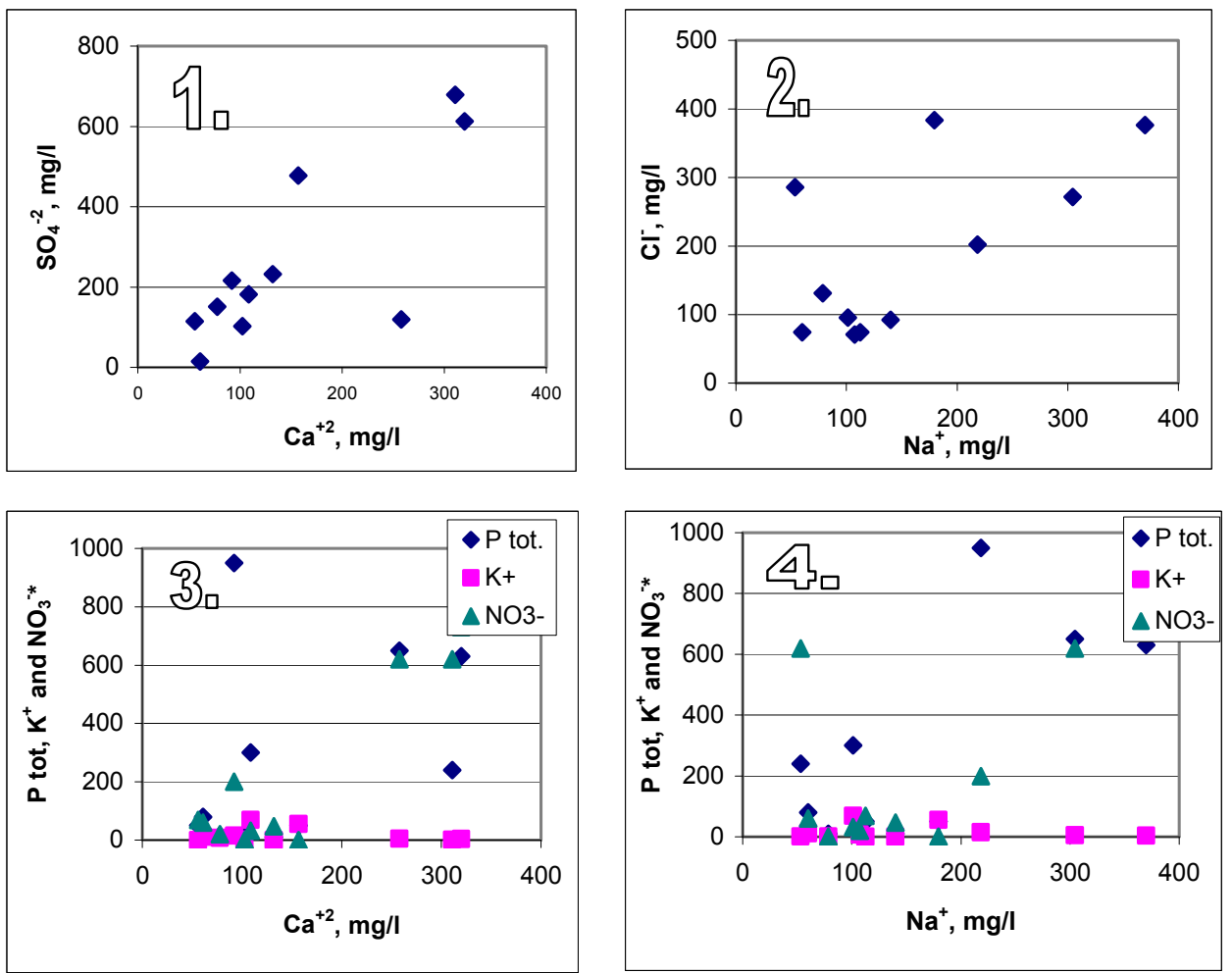

Figure 6. Scarce correlation between calcium and sulphate ions (diagram 1), respectively between sodium and chloride ions (2. diagram) showing possible natural origin of the "pollutant" anions. Lack of correlation between calcium (3. diagram) and sodium ions (4. diagram) versus total phosphor, potassium and nitrate anions: these ones represent the real pollutant substances

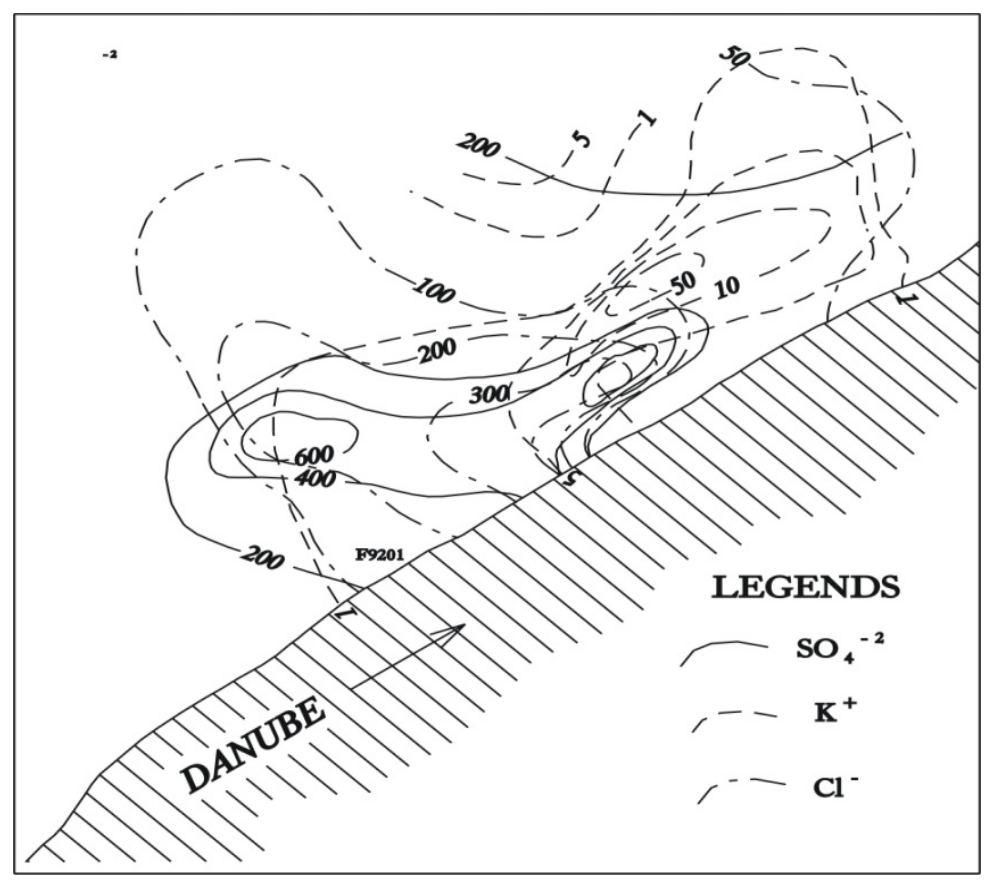

Figure 7. The distribution of sulphate, potassium and chloride ions: the displacement of the apex of the iso-lines marks the fractionation of the ionic content of the groundwater 


\section{Conclusion}

In the geotechnical stability of Galati city, two Pleistocene deposits have an important influence: the Barbosi clayey-silty formation and the loess and loess-type (slope) deposits. The underground water flow is limited by the first one, the effect being that of an impermeable bed. The lower part of the loess column is permanently saturated, causing the breakdown of its macroporous structure. Thus, in this deposit, the circulation of the groundwater is slow, and the content of soluble components indicates the presence of the areas with high concentration and of the probable traps of the underground streams. As in a giant ionic chromatographe, one part of the ions are released, while the others are "braked" in their movement. Unfortunately, this fact leads to the reactive zones between the "aggressive" (mainly anthropogenic) components of groundwater and the loess, up to the hydrostatic level. Here, the structure of the "dry" loess is modified, and finally, the equilibrium between the earth volume and the built objects becomes instable.

We hope that this kind of research projects can be very useful for the local administration, for developers, for people living in big towns, but also for anyone interested in environmental protection and safe development. We consider that the approach of the subject can be included in "the list of instruments" of a more generous and vast field of activity called "urban geology". This concept should have to be developed and put in practice as a valuable tool for policy makers.

\section{Acknowledgements}

The authors are indebted to dr. Danut Maria, Gabriel Popovici and Ionela Petraru from ISPIF Bucuresti, who contributed with their field observations, archive data and laboratory works, to Gábor Szurkos, dr. Péter Kovács-Pálffy and dr. Barbara Kerék from Hungarian Geological and Geophysical Institute, and last, but not least to mayor dr. eng. Constantin Munteanu, for his attentive interest in the geological and geotechnical problems of Galati city.

\section{References}

Botezatu, R., Bacioiu, T., \& Andrei, J. (1961). The relation among the gravity anomaly, the geological structure of Northern Dobrogea and the surrounded regions of Southern Moldavia and Eastern Muntenia. Acad. RPR, Geological Studies and Research, 1, 33-56.

Cotet, P. (1971). The Danube Delta—genesis and evolution. Peuce, I, 3-155.

Ghenea, C., \& Ghenea, A. (1959). Geological research in South-eastern edge of the Moldavian Platform. Archives of the Romanian Geological Institute, 1-27.

Gieseking, J. E. (ed.) (1975). Soil components. Vol. II. Inorganic components. Clay minerals (pp. 97-119). Berlin, Heidelberg, New York: Springer.

Liteanu, E., Pricajan, A. \& Baltac, G. (1961). Quaternary transgressions of the Black Sea on territory of the Danube Delta. Acad. RPR., Geological studies and research, VI(4), 22-30.

Macarovici, N., \& Jeanrenaud, P. (1958). Révue générale du Néogène de plate-forme de la Moldavie. The scientific annual of Al. I. Cuza University, Iasi (new series), II\&IV(2), 3-155.

Predescu, L. (1971). The Neolithic in the Popular Republic of Romania. Ed. Acad. RPR., 1-335.

Saulea, E., Ghenea, C., Bandrabur, T., \& Ghenea, A. (1968) Geological Map scale 1:20 0.000 L-35-XXII; L-35-XXIII 30, Focsani sheet. The Geology State Committee, the Geological Institute, Bucharest.

Sficlea, V. (1960). Contribution to the study of the loessoid deposits around Galati city. The scientific annual of Al. I. Cuza University, Iasi (new series), VI, 35-45.

Szurkos, G., \& Zsámbok, I. (2005) Urban Geology-a new branch of the geological sciences. The Scientific Bulletin of the North University from Baia Mare, series D., XIX, 78-85, Baia Mare.

\section{Copyrights}

Copyright for this article is retained by the author(s), with first publication rights granted to the journal.

This is an open-access article distributed under the terms and conditions of the Creative Commons Attribution license (http://creativecommons.org/licenses/by/3.0/). 